\title{
Europeanization and the Negotiation of a New Labour Migration Policy in Germany
}

The Goodness of Fit Approach Revisited

\author{
Barbara Laubenthal
}

CMS 2 (4): 469-492

DOI: 10.5117/CMS2014.4.LAUB

\begin{abstract}
The article focuses on the negotiation of a new labour migration policy in Germany in the years 2011 and 2012, and on the role that actors on both the regional and the European Union levels played in encouraging the introduction of a more open labour migration framework. Up until now, research has highlighted the German use of the European level for introducing more restrictive changes in migration policy. In line with these precedents, during the negotiation of a European policy for admitting highly-skilled migrants, Germany advocated a restrictive framework. However, at the transposition of the EU directive on highly-skilled migrants in national law, the German government used the directive as an opportunity to introduce a paradigm change in labour migration policies, establishing a significantly more open labour migration policy hitherto exclusively associated with Anglo-Saxon countries. The article will analyse the preconditions for this change, assessing the value of the goodness-of-fit approach for understanding processes of Europeanization.
\end{abstract}

Keywords: Europeanization, labour migration, highly-skilled migration, European Union, federalism

\section{The Europeanization of migration policies}

(...) We do not see any need for EU regulation at all. This question should remain a national competence. There will be no directive on labour migration, since the Bundesrat will not approve (Innenminister der Länder gegen Blue Card, 2007). 
With these words, the minister of the interior the federal state of Lower Saxony commented in December 2007 upon the European Commission's project to introduce an EU-wide residence title for highly-skilled migrants. However, five years later, the Bundesrat approved of the introduction of the so-called Blue Card, even opting for a more liberal labour migration framework than the European directive stipulated. Also, although Germany was one of the member states that took a sceptic stance towards the introduction of a common labour migration policy, the federal government used the provisions of the directive to significantly liberalize the German labour migration regime.

What happened between 2007 and 2012, and what can be learned about the dynamics and the tensions of Europeanization from this case? These are the questions that this article seeks to answer. At the same time, it aims at addressing the limited empirical foundation about European influences on national immigration policies' (Ette and Faist, 2007: 4). Compared to other policy fields, the field of migration policies has been rather neglected by research on Europeanization and on multi-level governance processes in the European Union. This is partly due to the fact that harmonization in the field of migration has only started comparatively late and is still weaker than in other policy fields. It is common knowledge in migration research that migration policies remain a central field of national sovereignty and an area of competence of the nation-state (Bendel, 2011a; Ette and Faist, 2007). Migration is commonly held to be a policy area 'where nation states are least likely to cede control' (Ette and Faist, 2007: 4). Thus '(...) the transfer of sovereignty from the member states to the European Union in decisions about migration and asylum, justice and order, continues to be one of the most surprising task expansions in the European project' (Bendel et al., 2011b: 9).

Still, migration policies have gradually been integrated at the EU level and since the late 1990 s have been characterized by a '(...) highly dynamic legislative process' (Bendel, 2011a: 371). Migration has become a field of multi-level governance: '(...) transnational co-operation in the fields of asylum and migration has taken the characteristics of a multilevel governance regime in the sense that the relevant actors $(. .$.$) can be found in$ Brussels, in certain national ministries and central agencies, and at the subnational level' (Guiraudon, 2000: 257). A central characteristic of the common migration policy is, however, that much policy-making in this area has overwhelmingly focused on migration control policies and on restricting migration to Europe: 'Since the treaty of Maastricht 1993 (...) the European immigration policy has basically developed emphasizing the 
dissuasive/exclusionary axis of its immigration policy' (Gsir, 2013: 91). Only since the year 2000, legal forms of migration and labour migration have been addressed by European legal projects. However, whereas the harmonization of migration control policies has significantly progressed, a further integration of labour migration policies in Europe is met by the majority of member states with a reluctance to give up national steering instruments. At the same time, research points to the role of domestic factors in bringing about a common European immigration policy. National governments have used the EU in the field of migration as an arena for circumventing national constraints, benefitting from operating in international venues and thereby bypassing national constraints (Guiraudon, 2000). This 'escape to Europe' (Geddes, 2003) accounts for a significant part of harmonization in the field of migration.

At first sight, Germany seems to be an exemplary case of this escape to Europe strategy. Research on the relationship between German domestic migration policies and the EU has overwhelmingly shown the use of the European level for introducing more restrictive migration policies. 'Political actors in Germany used developments on the EU level in order to prepare the ground for a domestic policy change' (Prümm and Alscher, 2007: 77). One of the most significant policy changes, the change of the German basic law on asylum towards a significantly more restrictive framework in 1993, was made possible by a partial transfer of competence to the EU. 'This shifting of the asylum and refugee policy was a tactical manoeuvre by the liberal-conservative government in order to be able to overcome the existing domestic asylum and refugee policy (...). Any consequent change to the liberal asylum law in Germany was now no longer a failure of German politics or the breaking of a taboo, but a consequence of decisions at the European level' (Hellmann et al., 2005: 152). The German Länder, too, have used the emerging multi-level governance field on migration, although their objective was to prevent an increasing harmonization. In the context of the ratification of the Maastricht treaty, the German federal states' co-determination rights in European matters were increased by the introduction of the so-called Europe article in the German basic law. Thus endowed with more political power and fearing growing financial burdens following from the admission of asylum-seekers, they repeatedly blocked attempts at introducing qualified majority voting, thus effectively preventing a further European integration (Hellmann et al., 2005: 153).

However, the case of the negotiation of a new labour migration policy in Germany goes contrary to these findings. The transposition of the "EU Directive $2009 / 50$ on the conditions of entry and residence of third-country 
nationals for highly-qualified employment", the so-called Blue Card directive, entailing a further harmonization of migration policies, was not only welcomed by federal and regional actors but led to an even more far-reaching liberalization of German labour migration law than the directive stipulates. As the OECD stated in its 2013 report on labour migration, 'recent reforms have put Germany among the countries with the fewest restrictions on labour migration for highly skilled occupations' (OECD, 2013: 15). In order to understand this surprising development, this article analyses the development of the public discourse on labour migration and the positions of key actors between 2010 and 2012, the timeframe in which the EU Blue Card directive was supposed to be transposed, and the role that the Blue Card directive played in this process.

In order to conceptualize the preconditions for the transposition of the Blue Card directive into German law, the article uses the goodness of fit approach. In initial research on the influence of the EU on the domestic level, goodness of fit, a concept that will be outlined in more detail below, was one of the most influential approaches for understanding the effects of European policies on domestic settings. However, after its initial success, the approach was increasingly criticized, some voices even arguing that it should be discarded. Contrary to these positions, I argue that the concept of goodness of fit still provides a valuable framework for understanding the interaction of the EU and the national context in bringing about policy change, and appreciating the preconditions for the Europeanization of migration policies. Taking into account both institutional and actor-related factors and analytically linking the national and the European level, this approach is able to capture the complexity of policy change in a multilevel system.

In order to analyse the preconditions for the use of EU policies as a motor for change at the domestic level, this article proceeds in three steps. After outlining the main characteristics of the goodness of fit approach and the criticism that it has raised, it describes the development of a common labour migration policy at the EU level. Then, by analysing positions of key actors and the evolving discourse on labour migration in the German context, the article argues that a trend towards a convergence of policy aims between the EU and the German domestic context in the field of labour migration took place. While up until now a "good fit" between the EU and the domestic context has been held to prevent major policy changes, in my analysis I intend to show that in the German case it was exactly the establishment of a state of goodness of fit that led to a paradigm change in German labour migration policy. 
The analysis is based on a mix of qualitative methods: (1) Expert interviews with the confederation of German employer associations (Bundesvereinigung Deutscher Arbeitgeber (BDA)); the Federal Ministry of the Interior, Unit of Immigration Law (BMI 1, BMI 2 and BMI 3) $)^{1}$; the Federal Ministry of Labour and Social Affairs, Department of labour market policy and employment of foreigners (BMAS 1); the Ministry of Labour and Social Affairs, Head of Unit of labour market policy and employment of foreigners (BMAS 2); the Ministry of the Interior of the free state of Saxony (SMI 1 and SMI 2); the Ministry of labour of the free state of Saxony (SMA); the CDU/CSU faction of the German Bundestag (CDU/CSU). (2) A qualitative content analysis of articles on labour migration in the national quality newspaper Süddeutsche Zeitung (SZ); coverage from 1 January 2010 to $3^{1}$ December 2011. All articles were analysed that contained the keywords labour migration, (highly)-qualified workers (hochqualifizierte Fachkräfte), labour shortage (Fachkräftemangel). (3) A document analysis of press releases and statements of political parties, employer associations, trade unions, research institutes and expert bodies on migration. ${ }^{2}$

\section{The dynamics of Europeanization: The goodness of fit approach}

Europeanization has been defined as 'the impact of (...) EU policy measures on the existing policies, political and administrative processes and structures of member states' (Héritier, 2005: 200). The term Europeanization ' (...) is most often associated with domestic adaptation to the pressures emanating directly or indirectly from EU membership' (Featherstone, 2003: 7). In order to understand processes of Europeanization that take place by the transposition and implementation of EU directives, an explanatory model that has been widely used is the goodness of fit (Risse et al., 2001) hypothesis. Originally formulated by Duina (1997), the goodness of fit hypothesis holds that '(...) smooth adaptation to EU policies depends on the degree to which these fit existing national policies and institutions' (Mastenbroek and Kaeding, 2006: 332). The original idea holds that the implementation of EU directives is determined by two nation-specific institutions: the organization of interest groups and policy legacies, i.e. national legal and administrative traditions: 'Implementation has depended on the relationship between directives and the institutions it targets. When a directive has demanded major transformations in these institutions, implementation has suffered; when a directive has been consistent with or 
strengthened current institutional arrangements, implementation has been successful' (Duina, 1997: 157). Thus the key idea of the concept is that the higher the degree of convergence between a directive and the national policy framework, the smoother the directive is transposed into national law. Other research on Europeanization has pointed to the importance of the similarity between EU and domestic projects and policies in order to bring about change, too. Radaelli (2003) states that one outcome of Europeanization can be 'inertia, (...) a situation of lack of change. This may (...) happen when a country finds that EU political architectures, choices, models or policies are too dissimilar domestic practice. Inertia may take the forms of $(\ldots)$ delays in the transposition of directives' (Radaelli, 2003: 37). However, adaptational pressure also serves as a motor for change: 'When adaptational pressure is low, because of the content of EU policy is already present in a member state, there is no need to change domestic institutions. Simply put, there is a good "fit" between national policy and the European Union. (...) At the other extreme, when the distance between EU policies and national ones is very high, member states will it find difficult to 'digest' (...) European policy' (Radaelli, 2003: 45) In other words, a 'bad fit' is the precondition for policy change. However, it also hinders the transposition of a European project on the domestic level.

Further research has gradually extended and modified the goodness of fit hypothesis. The concept has been expanded and several additional variables have been introduced. Windhoff-Héritier, et al. (2001) has stated that the capacity for change is influenced by formal veto positions (institutions) and factual veto positions and supportive coalitions (contending actors). She has conceived of the implementation of EU directives as a policy process of goal-oriented actors in a given political context that may restrict or facilitate implementation (Windhoff-Héritier, et al. 2001: 12). Radaelli (2003) draws attention to the timing and argues that in field of public policy the impact ' (...) of EU public policy is contingent on whether a country is already involved in a process of reform or not' (Radaelli, 2003: 47). As additional variables, he conceptualizes modes of legitimation and supporting discourses.

Most importantly, research that has further developed the goodness of fit approach has placed a special emphasis on the role of actors. Critical accounts of the hypothesis have stressed that "fit" is not a static given, but rather depends on positions and perceptions of actors (Radaelli, 2003: 45). From a "static" conception, focusing on the specific institutional arrangements of a nation-state, the focus of the concept has been widened to 
actors who perceive a goodness of fit, and/or who use adaptational pressures for promoting their policy aims (Börzel and Risse, 2003): '(...) the misfit between European and domestic processes, policies and institutions provides $(. .$.$) actors with new opportunities and constraints to pursue$ their interests' (Börzel and Risse 2003: 58). Duina (2007), too, in a reply to criticism on his original concept by Mastenbreoek and Kaeding (2006) emphasizes the role of actors and holds that key actors can push a directive despite misfit, or vice versa (Duina, 2007). He conceptualizes actors (state officials and interest groups) as the link between goodness of fit and ease of adaptation. Thus, both fit and actors matter (Duina, 2007).

Although the idea of "fit" was gradually made more complex and the concept was expanded towards a more dynamic framework taking into account various variables, some radical criticism has been formulated. Thus Mastenbroek and Kaeding (2006), referring to a number of empirical studies that contradict the goodness of fit hypothesis, have diagnosed its 'disappointing empirical results' (Mastenbroek and Kaeding, 2006: 334) and have come to the conclusion that the concept should be discarded. They suggest concentrating on the domestic context and on domestic actors' preferences or beliefs in order to explain the implementation of EU directives. However, in contrast to this view, I argue that goodness of fit is a valuable approach in order to capture the dynamics of the Europeanization of German labour migration policies between 2010 and 2012.

\section{The development of a common EU labour migration policy}

Much earlier than most of its member states and in particular Germany, the European Union started attempts to develop a common European labour migration policy. In 2000 which saw a Communication from the Commission to the Council and the European Parliament on a Community Immigration Policy, a common EU labour migration policy was proposed for the first time (Gsir, 2013: 94): '(...) the Commission recalled that (...) emphasis was to be placed on the need to develop an immigration policy designed to admit migrants mainly for economic reasons, as well as to address demographic decline (...). This European discourse was different from the dominant discourse of Member States in terms of programmatic ideas and policy solutions at the national level' (Gsir, 2013: 94). In 2001, the EU, 'presenting labour immigration as a solution to demographic problems dramatically highlighted by the United Nations Population Division report' 
(Gsir, 2013: 94/95) presented a directive on labour migration. However it was not accepted by the member states. In particular Germany and Austria were against it. Still, in 2005, the European Commission published a "Green paper" on an EU approach to Managing Economic Migration', reasserting a need for labour migration:

(...) even if the Lisbon employment targets are met by 2010, overall employment levels will fall due to demographic change. Between 2010 and 2030, at current immigration flows, the decline in the EU-25's working age population will entail a fall in the number of employed people of some 20 million. Such developments will have a huge impact on overall economic growth, the functioning of the internal market and the competitiveness of EU enterprises. (...) while immigration in itself is not a solution to demographic ageing, more sustained immigration flows could increasingly be required to meet the needs of the EU labour market and ensure Europe's prosperity (European Commission, 2005).

Several other reports and communications on the EU level assessed the importance of labour immigration and diagnosed a need because of decreasing fertility rates and demographic change:

(...) In a context of an ageing Europe, the potential contribution of immigration to EU economic performance is significant (...). According to the latest population projections, by 206o, the working age population of the EU is projected to fall by almost 50 million even with continued net immigration similar to historical levels and by around 110 million without such immigration. Such evolutions present risks for the sustainability of pensions, health and social protection systems and require increased public spending (European Commission, 2008).

Also, the EU's positions on immigration correlated with its Lisbon Agenda and the goal to become the world's most competitive economy in 2010: '(...) this [Blue Card] legislation aims to make Europe a player on the emerging global labour market, enhancing its competitiveness and luring highly skilled workers to Europe - and away from countries like the United States and Australia' (Collett, 2008).

In 2005, the policy plan on legal migration re-presented arguments for labour migration. However, based on the failure of a comprehensive approach, in its policy proposals the European Commission opted for a sectoral approach, proposing three different directives. In 2007 the Blue Card 
directive was presented. The directive provided common rules on entry and residence for highly-qualified workers and their families. Workers who meet certain criteria (the existence of an employment offer or job contract; higher professional qualifications; compliance with a minimum salary threshold (at least 1.5 times the average of the gross annual salary of the state) may take up an employment in any EU member state (Gonzalez et al., 2013; von Weizsäcker, 2006). Although it was expected that the approval of the directive would take place rather smoothly, in reality it proved to be controversial. Especially Germany formulated doubts and stressed that first national labour potential should be exhausted (Meyer, 2010). The admission criteria and salary threshold proposed by the EC also raised controversy, and '(...) a major opponent to the level proposed by the Commission was Germany' (Meyer, 2010: 22).

\section{The evolution of German labour migration policies between 2000 and 2010: small changes, small effects}

While during the negotiations of the Blue Card in Brussels some changes in German labour migration policy took place, the German model still remained rather restrictive, prioritizing the national work force: 'Every university graduate with a degree that is recognised in Germany can work in Germany, if no national is available. That is the German immigration law in one sentence' (BMAS, 18.11.2011). This statement summarizes the basic principle of the German labour migration policy until the year 2010, when Germany was expected to transpose the EU Blue Card directive into national law. Despite some changes towards an opening of the labour market for highly-skilled migrants, the German labour migration law represented a demand-driven model based on a concrete job offer, and albeit with exceptions for a very narrow group of people, an overall restrictive framework with a reluctance to create permanent settlement possibilities: 'The permanent settlement permit means that if the day after you got it you become unemployed, you can work as a taxi driver. Then you can kill the person who gave it to you, and you can still stay. It is as if you meet somebody and you marry him on the same day, in a country that does not have a divorce law. I would not do that' (BMAS, 19.11.2011).

From the beginning of the 1970s until the year 2000, the country's policy on labour migration was guided by the principle of recruitment ban and focused on preventing labour migration to Germany. Although since the end of the 1980s channels for labour migration from outside the EU have 
existed, only temporary labour migration was admitted. The guiding principle of "Germany is no immigration country" was not only reflected in the lack of integration policies, but also in a restrictive framework on labour migration, aiming, albeit with a few exceptions, at preventing labour migration to Germany. Until the passing of the first immigration law in 2005, only channels for temporary labour migration into specific labour market segments existed.

In 2005, a change in labour migration policies took place, and in the following years the preconditions for the access to the German labour market for highly-skilled migrants were gradually lowered. The 'Law for Managing and Containing Immigration and for the Regulation of the Residence and Integration of EU citizens and Foreigners' (Gesetz zur Steuerung und Begrenzung der Zuwanderung und zur Regelung des Aufenthalts und der Integration von Unionsbürgern) for the first time established channels for permanent labour immigration that were conceptualized as a regular option and not as an exception. Specific channels for the access of highly-skilled migrants to the labour market were created. This group could now obtain a permanent settlement permit. However, a high salary threshold (86,40o Euro) for taking up employment in Germany still restricted the immigration of highly-skilled migrants. Also, the new immigration law maintained the principle of a general recruitment stop.

In 2007 and 2009, further legal and administrative changes took place that liberalized the channels for highly-skilled migration. The Law for the management of labour migration that came into force on 1. January 2009 lowered the required minimum income for highly-skilled migrants under paragraph 19 from 86,400 to 63,6oo Euro. ${ }^{3}$ However, the legal provisions for highly-skilled migration had more a symbolic than a material effect. Between 2007 and 2011, less than one-thousand migrants used the paragraph 19 to take up employment in Germany.

All in all, until the transposition of the Blue Card directive, the overall framework remained restrictive and prioritized the national workforce. Changes towards a more open labour migration regime still took place within a system whose main feature was a conditional labour market access for third-state migrants. Apart from those using the legal channel for highly-skilled migrants, all labour migrants were subjected to the socalled priority check (Vorrangprïfung) that is carried out on a case-by-case basis for each single job application. In this process, the Federal Employment Agency and the foreigner's office examine if a national or an EU citizen is available for the job. Citizens from outside the EU can only take up the position if no national worker is available. 


\section{$5 \quad$ The transposition of the EU Blue Card directive into German law: conflicts and opportunities}

However, during the phase of the transposition of the Blue Card directive, the restrictive German framework was more and more challenged by some government actors and a new discourse that centered on Germany's need to remain economically competitive. The transposition of the Blue Card directive was supposed to take place in December 2010, in the context of the transposition of several EU directives, i.e. the returns directive and the employer sanctions directive. A law project comprising the three directives had been prepared by the Ministry of the Interior at the end of 2009 . However, in 2010 the Blue Card directive was taken out again of the second Directives Implementation Law (Zweites Richtlinienumsetzungsgesetz) (Basse et al., 2011). 'Against the background of public debates on skilled labour, and debates on the topic within the governing coalition, the directive on highly-skilled migrants was excluded from the law project' (Basse et al., 2011: 363). The reason lay in conflicts within the government, and the opposition of the Bavarian conservative CSU against the EU Blue Card (BMI, 22.11.2013). One reason given by the CSU for its opposition was the fear that the realization of the full freedom of movement for the EU accession countries in May 2011 would lead to a high amount of immigrants from these countries (BMI, 22.11.2013). The CSU also embedded its position in a discourse generally critical of non-EU foreigners. In September 2010 its chairman stated that 'Germany is not an immigration country'. Also, he explicitly positioned himself against a points-based system and against the introduction of quotas for certain sectors or professions. He demanded that the evaluation procedure of requests for residence permits should not only evaluate the qualification of the potential labour migrant, but also his or her 'willingness to integrate' (Die Welt, 16.10. 2010). On the opposite side, the liberal party FDP was against the transposition of the directive in the form foreseen by the legal project, arguing that the Blue Card directive should be used for the introduction of a more comprehensive labour migration framework. Thus for very different reasons, both smaller coalition partners opposed transposing the directive at this point.

\subsection{A changing discourse on labour migration}

However, while the transposition of the Blue Card directive became the object of a controversial debate within the government, the public discussion about a need for foreign skilled labour intensified. Since the year 2010, various actors have diagnosed the so-called Fachkräftemangel, a shortage 
of skilled labour, and it has become a topic of growing importance both in the media coverage and in the political sphere. A number of studies and expert reports were published on the issue, and interest groups increasingly brought the subject into the public sphere. National actors, such as the Association of German Engineers (Verein Deutscher Ingenieure) and the Federal Association of Information Services, Telecommunication and New Media (Bundesverband Informationswirtschaft, Telekommunikation und neue Medien e.V. (Bitkom)) issued reports stating that their sectors lacked several tens of thousands of qualified workers. Regional actors, too, published figures on labour shortages. The Chamber of Commerce of Stuttgart declared that in 2014, up to 85,000 skilled workers would be lacking in Baden-Württemberg (IHK Region Stuttgart, 2011). The Bavarian economic association (Vereinigung der bayerischen Wirtschaft) identified a lack of more than 500,000 qualified workers that in 2030 would increase to more than one million (Scharnitzky, 2011). In the same vain, the Cologne Institute for Economic Research (Institut der Deutschen Wirtschaft Köln) calculated that in 2020 the shortage in the so-called MINT ${ }^{4}$ professions would amount to 426,000 . Also, a number of government bodies and research institutions published projections on the future development of the German work force and figures on the immigration level needed to compensate losses due to demographic change. According to the German Institute for Economic Research (Deutsches Institut für Wirtschaftsforschung) Germany needed a net immigration of 500,000 per year in order to secure its economic force (Newsletter Migration und Bevölkerung, 2010). In February 2011 the Federal Employment Agency (Bundesagentur für Arbeit) published a report on the ongoing Fachkräftemangel. stating that Germany needed to establish a "welcoming culture" and that a short-term immigration of 0.4 million to 0.8 million foreign workers would be necessary (Bundesagentur für Arbeit, 2011). Actors such as the Sachverständigenrat deutscher Stiftungen für Integration und Migration, an expert body founded by several foundations, elaborated a projection on the future evolution of the German work force. According to this calculation, without any immigration, between 2008 and 2060 the labour force would decrease by 373,000 per year; with a medium-level immigration, it would decrease by 313,000 and with a high level of immigration (plus 200,000 yearly, starting in the year 2020), by 247,000 (SVR, 2011: 44).

At the same time, a consensual discourse emerged that acknowledged Germany's need for labour migration. Although positions on which instruments should be introduced sometimes widely differed, key state and nonstate actors all agreed that Germany needed a "welcoming culture" and hat 
to successfully participate in the ongoing "global competition for the brightest minds": "The competition for the brightest minds is intensifying (...) Especially regarding the establishment of a welcoming culture, many things need to be done. Where can the accompanying spouse work, where are schools for the children, these are important questions for migrants. (...). At the universities, for scientists, these issues are already well-taken care of, but in the economic sector, much remains to be done' (BMI 1, 17.11.2011). 'German companies are part of a global competition for the brightest minds (...). It is clear that we need qualified workers in order to secure our welfare in the global competition' (Bundesministerium für Arbeit und Soziales, 2010): 'If you have a look at the EU, the competition for the brightest minds is in full process, and we are already lagging behind because we have lost the first immigration waves from the EU 8, others have been faster' (BDA, 17.11.2011).

\subsection{Controversies and pro-liberalization positions within the federal government}

The preparation of the transposition of the EU Blue card into German law took place during a time when a new dynamic in the political and public negotiation of German labour migration policies developed. The debate was characterized by attempts of part of the governing coalition to significantly liberalize the existing labour migration framework, and ensuing conflicts both within and between the governing parties. The controversy centered on the preconditions that should be attached to the granting of a settlement permit to highly-skilled migrants.

At the end of 2010 a controversy started between the governing parties CDU/CSU on one side and the FDP on the other side (Höll and Öchsner, 2010). The liberal party FDP wanted to lower the income threshold for highly-qualified migrants. The liberal minister of justice criticized its coalition partner: 'The reluctance of the CDU to tackle the issue of labour migration management is not proof of a rational immigration policy' (Preuß, 2011b). 'Who do we want to invite to Germany? Who can be a motor for our society? (...) Currently Germany is losing in the competition for the brightest minds'. Within the CDU, opposing positions on the issue existed. Both the Minister of Labour and the Minister of Science demanded, against the positions of their own party faction in the Bundestag, the introduction of a points-based system and a lower income threshold for the highly-qualified. The CDU/CSU faction of the Bundestag and the CDU Minister of Interior were against these plans (Preuß, 2011a).

Another factor that influenced the debate on the liberalization of labour 
migration was the issue of freedom of movement for citizens of the new 2007 accession countries. Germany had restricted the freedom of movement of citizens from these countries until the 01.05.2011. An important argument of those actors with a restrictive position was the "fear" of a mass immigration after the opening towards the EU-8. After the establishment of the full freedom of movement in May 2011, however, immigration numbers remained low. Key labour migration actors agree that these low immigration numbers helped to bring about the change towards a less restrictive labour migration model (BDA, 17.11.2011; BMI 2, 2.04.2012; SMI 1, 7.07.2012; SMA, 21.07.2012):

The first May 2011 certainly demystified the issue (...) In fact everybody knows that Germany is not a country where qualified foreigners are queuing up and where we just have to open the borders and masses will stream in. And one has seen that now at the opening for the EU-8. The low immigration figures from the new EU member states have brought a new dynamic into the debate, making it easier for the government to adopt a more liberal approach, since fears of being "overrun" have not been justified. (BMAS, 9.02.2012)

Also, the favourable economic situation and the comparatively low unemployment figures served as a window of opportunity for change: 'The labour market situation has considerably changed during the last two years. We have much less unemployed people. And the need for migration depends on the labour market' (CDU/CSU, 10.02.2012).

Finally, those parts of the government who were in favour of a more open labour migration policy gradually were successful. In June 2011, on the initiative of the Christian-Democratic Minister of Labour, the government issued a so-called positive list of professions (Positivliste) that would not be subject to the priority check anymore. The list included mechanical engineers, electronic engineers and doctors. ${ }^{5}$ On 6 November 2011, the government agreed to yet again reform paragraph 19 Residence Law and to lower the required minimum income for university graduates to 48,00o Euro.

\subsection{The Länder as actors in labour migration policy}

During the negotiation of a new labour migration framework and during the phase in which the transposition of the EU Blue Card directive was discussed, the position of the representation of the German Länder changed from a restrictive position towards demands for a significant liberalization of the German labour migration regime. In the German political 
system, the representation of the Länder has several competences in the political process. Legislative projects by the federal government must be first presented to the Bundesrat; also, it can introduce its own legislative projects. The Bundesrat must approve those laws that have a direct effect on the financial or administrative structure of the Länder. It can veto all other laws; however, this veto can be overridden by the national parliament. In 2007, confronted with the proposal on the EU Blue Card directive, it had rejected the idea of a common residence title: 'The Bundesrat demands to ensure that the principle of subsidiarity is upheld and stresses (...) the competencies of the member states to regulate the access to their national labour markets (...)' (Bundesrat, 2007). It also rejected the idea to allow immigration based on compliance with a minimum salary threshold.

However, in the following years, the representation of the German regions gradually changed its position. One of the first and most active actors who demanded better and more generous immigration channels for skilled labour was the free state of Saxony. Saxony is an instance of an Eastern German federal state where since the reunification the population has rapidly decreased, and where at the same time a significant economic growth is taking place. Since 1990, the population has decreased by 15 percent, and projections show that until 2025, it will decrease by another 12 percent. In 2014, more people will leave the employment sector than will take up an employment. Due to historical reasons, Saxony has a specific, non-EU migration profile. While in the western federal states a tradition of intra-EU labour migration from Italy and Spain exists that encourages new migration from these countries, the Eastern German Länder's historical migration ties with Eastern European countries who until recently have not been in the EU, or who still are not EU members. The main countries of origin of migrants living in Saxony are Vietnam, Russia, Ukraine and Poland (Landtag Sachsen, n.d.).

Confronted with the pressure of a lack of skilled workers and the danger of companies not expanding because of this situation, in 2008 the government of Saxony defined and established a new policy field, "Gaining by migration" (Zugewinn durch Zuwanderung), and set up a corresponding department in the Ministry of Interior. The existing legal provisions for the immigration of skilled labour were considered to be ineffective: 'The law of 2005 was useless because the salary threshold was too high' (SMI 1, 7.07.2012). In 2009, Saxony commissioned a study on the future of labour migration by the research institute Institut der Zukunft der Arbeit (IZA). The study recommended the introduction of a system with a yearly quota for immigration, combined with a points system that would take into 
account qualification, language skills and professional experience (Hinte et al., 2011). In April 2011 the federal state of Saxony brought an initiative based on the IZA report to the Bundesrat. Although also governed by the CDU, the proposition of Saxony was contrary to the position of the federal government and of the CDU on the federal level. However, '(...) that is federalism for you. The interests of the region overpowers party interests' (SMA, 21.07.2012).

The Blue Card directive both provided a "blueprint" for the initiative of the Saxon government and helped to draw attention to Saxony's initiative. One motive to introduce the Bundesrat initiative was that the Blue Card directive was not being transposed (SMI, 17.07.2012): 'We have built our Bundesrat initiative knowing the Blue Card directive, and we have adapted elements of the Blue Card directive' (SMI, 17.07.2012). However, at first Saxony could not find allies for its proposal amongst other regions. In this situation, the Blue Card directive served as an opportunity for underlining the demands of the Saxon government 'The EU initiative helped us (...). In the context of its negotiation, we could draw attention again to our initiative in the Bundesrat' (SMA 21.07.2012). When Germany was lagging behind with the transposition, the directive became a "catalyst" (SMI, 17.07.2012).

Gradually, other federal states also developed positions in favour of a more open labour migration regime. In December 2011 the conference of the ministers of economy of the 16 Länder demanded a paradigm change in labour migration policy, towards a welcoming culture and the attraction of skilled foreign workers (Beschluss der Wirtschaftsministerkonferenz, 2011). Hamburg established a welcome centre for labour migrants at its aliens' office. 'Between 2007 and 2012, it became widely accepted that we will be confronted with a lack of skilled workers that cannot be addressed by the national workforce or solely by EU labour migrants. It took the Länder a bit longer to realize this, but they did' (BMI, 3 24.02.2014). 2012, in its note on the federal government's Blue Card legislative project, the Bundesrat had, compared to 2007, significantly changed its position on the Blue Card. It 'explicitly welcomed the introduction of the Blue Card' and demanded even more far-reaching changes than the Blue Card directive contained. The Bundesrat proposed to allow labour immigration of migrants who are not university graduates but who have a comparable five years professional experience. It also suggested the introduction of a skills-based labour immigration channel, namely the introduction of a 'job search visa', a proposition that was taken up by the federal government when it transposed the Blue Card directive (Bundesrat, 2012). 


\subsection{The transposition of the Blue Card directive}

In December 2011 the federal government decided on a draft legislation transposing the EU Blue Card directive into German law. In March 2012 it announced that it had come to an agreement on the way of transposing the Blue Card directive, and on the further measures that would accompany the introduction of the Blue Card. 'Basically the Blue Card directive only provided a general framework, and it was up to the national governments to decide on how attractive they would make this new residence title for highly-skilled migrants. For us, the EU directive was an opportunity. We wanted to lower the minimum income threshold anyway (...)' (BMI 3, 24.02.2014). At the time of the transposition of the directive, the existing national legal provisions regarding the required minimum salary for highly-skilled migration were already almost identical to the provisions of the Blue Card: 'It was the national decision-making process that was decisive for the introduction of the Blue Card' (BMI 3, 24.02.2014). The Blue Card directive served as a "vehicle" (BMI, 24.02.2014; SMI 2, 01.03.2014) for bringing about a policy change that already was intended by the federal government.

In August 2012, the law on the transposition of the EU directive on highly-skilled migration (Gesetz zur Umsetzung der HochqualifiziertenRichtlinie der Europäischen Union) came into force. With it, the federal government agreed on a new legal framework with far-reaching consequences for the German labour migration regime. The EU Blue Card that was introduced became a new residence title, replacing paragraph 19 of the Residence Act. The Blue Card can be granted to university graduates from outside the EU who earn more than 44,80o Euro/year. For the MINT professions, the required minimum income is set at 34,900 Euro. In its transposition, the German government lowered the minimum salary threshold as far as it is made possible by the Blue Card directive. Also, the German transposition foresees the shortest time frame for processing the Blue Card (14 days) (Kosc, 2013: 8). ${ }^{6}$ As opposed to the regulations of the former paragraph 19 Residence Act, holders of the Blue Card at first only get a temporary residence title. This can be viewed as a concession to the Bavarian CSU and parts of the CDU. After three years of continuous employment in Germany, however, the residence title can be transformed into a permanent settlement permit. Blue Card holders with very good German language skills may be granted a permanent settlement permit after two years. Another new regulation that was introduced with the Blue Card transposition is a so-called job search visa. It gives university graduates from every country in the world the possibility to obtain a six-month visa 
for a job search in Germany. The introduction of this instrument was suggested by the Bundesrat and taken up by the federal government. The only precondition is that they can prove that they have the financial means to sustain themselves during their stay in Germany. The introduction of this instrument as $\S 18 \mathrm{c}$ into the new immigration act introduces a human capital based instrument, up until now associated with Canada and the USA, into the previously solely employment-driven German system (Kolb, 2014b). This represents not only a departure from the long prevailing philosophy that labour immigration to Germany was only possible with a work contract. It also means that in fact a very basic points system consisting of two accession criteria, i.e. an academic qualification and adequate means of subsistence during the stay in Germany, was introduced into the German labour migration regime (Kolb, 2014b: 66).

Furthermore, the law also abolishes the regulation of paragraph 19 Residence Act according to which self-employed foreigners must invest 250,000 Euro and create five jobs in order to obtain a settlement permit in Germany. Finally, the legislation also entails a change for foreign students. From now on, foreign university graduates may take up any job during the "search year" in which they are entitled to look for an employment in Germany (and not only if it is considered to be corresponding to their degree of qualification). After having been employed for two years, they can be granted a permanent settlement permit. Also, foreigners who have been doing their vocational training in Germany may take up employment in Germany after their training.

\section{Conclusion: Preconditions for the Europeanization of German labour migration policy}

With the transposition of the EU Blue Card directive, the German labour migration regime has been significantly liberalized and has undergone a paradigm change. By lowering the salary threshold for taking up employment in Germany as far as made possible by the Blue Card directive, the concept of "highly-qualified" was redefined and now means migrants with a salary that is only slightly higher than the national average gross salary. Furthermore, with the transposition, a skills-based, offer-oriented labour migration instrument was introduced into the up until now exclusively demand-oriented German legal framework. The reform significantly increases the possibility of access of third-state migrants to the German labour market. In fact, in European comparison, in 2012 Germany was the 
country that had issued the highest amount of Blue Cards in the EU (2584), thus having delivered 86 percent of all Blue Cards (Kosc, 2013: 15).

This transposition of the Blue Card directive must be seen as the final point of a national development towards a more open labour migration regime. Since 2010, the debate about the need for skilled foreign labour gained momentum. In 2010, at the time when Blue Card directive was supposed to be implemented, a controversial debate on labour migration took place. Ultimately, those actors who were in favour of a further opening of the German labour market to third-state migrants were successful. Both key actors on the federal level and at the subnational level demanded a liberalization of the German migration law. At the same time, a public discourse on Germany's need to remain internationally competitive intensified, strongly mirroring the discourse on labour migration at the EU level. In the German case, some actors used the Blue Card directive as an opportunity for promoting their ideas. However, at the same time, and maybe more importantly, a development towards a convergence of political discourses and policy goals between the EU and the German political context took place. The directive was transposed when the policy preferences by national key actors and the domestic discourse on the subject had become almost identical with the content of the Blue Card directive. Then not only the directive was transposed; rather, EU legislation was used to bring about a major policy change that represents a paradigmatic shift in German labour migration policy. In an internationally comparative perspective, regarding its management of labour migration Germany has changed from a 'restrictive maverick to a liberal role model' (Kolb, 2014a: 91). With the most recent reforms, a rapid policy change in German labour migration policy has taken place: 'After many years of a reluctant position towards labour migration at best, Germany since 2012 has introduced immigration channels that in an internationally comparative perspective are liberal and open' (SVR, 2014: 15). The German development also fits into a general international trend towards hybrid models of labour migration regulation that combine both employer-based and human-capital oriented instruments (Kolb, 2014a; Papademetriou and Sumption, 2011). Austria, which in the negotiation of the Blue Card on the EU level also took a sceptic stance, in 2011 introduced a human capital based approach, too. The RotWeiß-Rote Karte is a points system for highly-qualified workers and workers in shortage professions. With the red-white-red card, highly-skilled migrants can obtain a six month visa to look for employment in Austria.

In order to understand the rapid and paradigmatic change in German labour migration policy, this article has discussed the concept of goodness 
of fit with the aim of evaluating how valuable the approach still is for understanding processes of Europeanization and the impact of the EU level on the domestic context. The case of the German Blue Card transposition confirms two of the central hypothesis of the goodness of fit approach: that directives are smoothly transposed if they fit the domestic institutions and policies; and that actors perceive and use an EU legal project for promoting their ideas. The German case shows that "goodness of fit" can (or should) be understood as a process rather than a static concept: as a precondition for the transposition, EU and domestic policy aims first had to reach a degree of conformity. Then, this "good fit" encouraged a significant policy change in the field of German migration policies, even transcending the aims of the EU directive. Thus, the German case shows that an EU directive can also be a vehicle for a broader policy change. It is another instance of how a government seeking reform uses the European level (Radaelli, 2003). However, it is also worth noting that an emphasis on a low degree of (intra-EU) migration (the low immigration rates after the establishment of the freedom of movement for the 2004 accession countries in 2011) served as an important precondition for the opening of the German labour migration regime.

The case of the German Blue Card transposition shows that the concept of goodness of fit, understood as a framework for understanding the interaction and the interdependency of the EU and the national level, still is a useful concept that should not be discarded. Focusing exclusively, as some authors have proposed, on the national context for understanding the impact of European politics and policies on the domestic level, would mean a return to a methodological nationalism that would block the view for the processes of multi-level governance that undoubtedly take place in the field of European labour migration. All in all, the case of the German Blue Card transposition provides a valuable instance to understand processes of Europeanization, from a policy field hitherto comparatively neglected by Europeanization research.

\section{Notes}

1. Three interviews took place with representatives of the Ministry of the Interior: one interview with a civil servant of the unit immigration law (BMI 1) and two interviews with the head of the unit immigration law (BMI 2 and BMI 3 ).

2. Most of this empirical material was generated in the framework of the research project "Labour Migration Governance in Contemporary Europe" (2012 to 2014), directed by Dr. Ferruccio Pastore, FIERI, Torino and has also been presented in Laubenthal (2012). 
3. Now the salary had to at least correspond to the income threshold to the pension insurance scheme. In 2012, the income threshold to the pension insurance scheme was at 67,200 Euro/year in Western Germany and at 57,60o Euro in Eastern Germany.

4. Mathematics, information technology, natural sciences, technology.

5. It is however interesting to note that the already existing law would have permitted the same, too: professions could have been exempted from the priority check by applying paragraph 39 (2) Residence Act which states that the Federal Employment Agency of Labour can agree to the issuing of a residence permit under paragraph 18 if this appears to be necessary for certain professions or economic sectors.

\section{References}

Basse, S., Burbaum, A.M. \& Richard, C. (2011). Das »zweite Richtlinienumsetzungsgesetz« im Überblick [An Overview on the Second Directives' Implementation Law]. Zeitschrift für Ausländerrecht und Ausländerpolitik, n1/12, pp. 361-368.

Bendel, P. (2011a). Asylum and migration policy. In: Heinelt, H. \& Knodt, M. (Eds.). Policies within the EU multi-level system. Instruments and strategies of European governance. Baden-Baden: Nomos, pp. 371-385.

Bendel, P., Ette, A. \& Parkes R. (Eds.). (2011b). The Europeanization of control: venues and outcomes of EU justice and home affairs cooperation. Berlin/Münster: Lit.

Börzel, T.A., \& Risse, T. (2003). Conceptualizing the Domestic Impact of Europe. In: Featherstone K. \& Radaelli C.M. (Eds.). The Politics of Europeanization. Oxford: Oxford University Press, pp. $57-80$.

Bundesministerium für Arbeit und Soziales (2010). Allianz zur Beratung der Bundesregierung in Fragen des Arbeitskräftebedarfs [Alliance for the Consultation of the Federal Government Regarding Labour Demands]. Retrieved from ttp://www.bmas.de/SharedDocs/Downloads/ DE/PDF-Publikationen/a165-allianz-zur-beratung-der-bundesregierung.pdf?_blob=publicationFile

Bundesrat (2007). Retrieved from http://www.bundesrat.de/nn_26415o/DE/presse/pm/2007/1972007.html

Bundesrat (2012, February 7). Stellungnahme des Bundesrates [Statement of the Bundesrat], Drucksache 848/11.

Collett, E. (2008). The Proposed European Blue Card System, Arming for the Global War in Talent? Retrieved from http://www.migrationinformation.org/Feature/display.cfm?id=667 $\mathrm{l}$

Duina, F. (1997). Explaining Legal Implementation in the European Union. International Journal of the Sociology of Law, 25(2), pp. 155-180.

Duina, F. (2007). Domestic Actors and Europeanization: Why 'Fit' Still Matters. Comparative European Politics, 5, pp. 339-341.

Ette, A. \& Faist, T. (2007). The Europeanization of national policies and politics of immigration: Research, question and concepts. In Faist, T. \& Ette, A. (Eds.). The Europeanization of national policies and politics of immigration. Between autonomy and the European Union. Basingstoke [England]; New York: Palgrave Macmillan, pp. 3-31.

European Commission (2001). Proposal for a council directive on the conditions of entry and residence of third-country nationals for the purpose of paid employment and self-employed economic activities. COM (2001) final 386. 
European Commission (2005, January 11). Green paper on an EU approach to managing economic migration. COM 811 final.

European Commission (2008, June 17). Communication from the Commission to the European Parliament, the Council, the European Economic and Social Committee and the Committee of the Regions - A common immigration policy for Europe: Principles, actions and tools. COM 2008359 final.

FDP attackiert Seehofer [FDP attacks Seehofer]. (2010, October 19). Süddeutsche Zeitung. p. 1.

Featherstone, K. (2003). Introduction: In The Name of Europe. In: Featherstone, K. \& Radaelli, C.M. (Eds.). (2003). The politics of Europeanization. Oxford: Oxford University Press, pp. 3-27.

Featherstone, K. \& Radaelli, C.M. (Eds.). (2003). The politics of Europeanization. Oxford: Oxford University Press.

Geddes, A. (2003). Still Beyond Fortress Europe? Patterns and Pathways in EU Migration Policy. Belfast: Queens University.

González, C., Parkes, R., Sorroza, A. \& Ette, A. (2013). The EU Performance in the Global Competition for Highly-Skilled Migrants. Retrieved from http://www.notre-europe.eu/media/highlyskilledmigrants-gonzalezzparkessorrozaette-ne-jdi-feb13.pdf?pdf=ok

Gsir, S. (2013). EU Labour Immigration Policy: Discourses and Mobility. Refugee Survey Quarterly, 32 (4), pp. 90-111.

Guiraudon, V. (2000). European Integration and Migration Policy: Vertical Policy-making as Venue Shopping. Journal of Common Market Studies, 38 (2), pp. 251-271.

Hellmann, G., Baumann, R., Bösche, M., Herborth, B. \& Wagner, W. (2005). De-Europeanization by Default? Germany's EU Policy in Defense and Asylum. Foreign Policy Analysis, 1 (1), pp. 143-164.

Héritier, A. (2005). Europeanization East and West. A Comparative Assessment. In: Schimmelfennig, F. \& Sedelmaier, U. (Eds.), The Europeanization of Central and Eastern Europe, Ithaca/ New York: Cornell University Press.

Hinte, H., Rinne, U., Zimmermann, K.F. (2011). Ein Punktesystem zur bedarfsorientierten Steuerung der Zuwanderung nach Deutschland [A Points-Based System for Managing DemandOriented Immigration to Germany], IZA research report no. 34 .

Höll, S. \& Öchsner, Th. (2010, December 8). Bildung statt Zuwanderung. SPD fordert 20-Milliarden-Plan gegen Fachkräftemangel [Education Instead of Immigration. SPD Demands a 20Billion-Plan Against Labour Shortages]. Süddeutsche Zeitung.

Horst Seeehofer hat einen Sieben-Punkte-Plan [Horst Seehofer has a Seven-Point-plan]. Die Welt (2010, October, 16).Retrieved from http://www.welt.de/politik/deutschland/article10330902/ Horst-Seehofer-hat-einen-Sieben-Punkte-Plan.html

IHK Region Stuttgart (2011, October, 5). Jeder zweite Betrieb kann offene Stellen nicht besetzen [Every Second Company Cannot Fill Open Positions]. 49/11.

Innenminister der Länder gegen Blue Card [Ministers of Interior Against Blue Card] (2007, December 8). Frankfurter Allgemeine Zeitung , p. 2.

Kolb, Holger (2014a). Vom 'restriktiven Außenseiter' zum 'liberalen Musterland' - Der deutsche Politikwechsel in der Arbeitsmigrationspolitik [From A 'Restrictive Maverick' to a 'Liberal Role Model' - The Policy Change in German Labour Migration Policy]. In: Rüb, Friedbert (Eds.), Rapide Politikwechsel in der Bundesrepublik. Theoretischer Rahmen und empirische Befunde, Baden-Baden: /Nomos/, pp. 71-92.

Kolb, Holger (2014b). When Extremes Change. German and Canadian Labour Migration Policy Compared. Comparative Migration Studies, 2 (1), pp. 57-75.

Kosc, P. (2013, September). Domestic adaptation and modalities of the implementation of the Blue Card directive. Paper presented at the European Consortium for Political Research 7 th General Conference, Bordeaux, France. 
Landtag Sachsen (n.d.). Retrieved from http://www.landtag.sachsen.de/dokumente/sab/20110114Statistik

Laubenthal, Barbara (2012). Labour migration governance in contemporary Europe. The case of Germany. April 2012. Torino: FIERI.

Mastenbroek, E. \& Kaeding, M. (2006). Europeanization Beyond the Goodness of Fit: Domestic Politics in the Forefront. Comparative European Politics, 4 (4), pp. 331-354.

Meyer, N.Y. (2010). The European Union blue card directive: What were the main reasons to introduce the EU Blue Card directive and what was the final result after two years of political debate? (Bachelor thesis). University of Twente. School of Management and Governance.

Newsletter Migration und Bevölkerung. (2010). no. 7.

OECD (2013). Recruiting Immigrant Workers: Germany 2013, OECD Publishing.

Papademetriou, D. \& Sumption, M. (2011, June). Rethinking Points Systems and Employer-Selected Immigration.. Washington DC: Migration Policy Institute.

Preuß, R (2011a, June 3). Akademiker für Deutschland. Berlin will den Zuzug ausländischer Fachkräfte erleichtern [University Graduates for Germany. Berlin Wants to Make Immigration of Foreign Qualified Workers Easier]. Süddeutsche Zeitung, p. 19.

Preuß, R. (2011b, May, 12). Kritik an Fachkräfte-Plan. Justizministerin attackiert Papier der Bundesregierung [Criticism on the Plan for Qualified Workers. Minister of Justice Attacks the Federal Government]. Süddeutsche Zeitung, p. 5 .

Prümm, K. \& Alscher, S. (2007). From model to average student: the Europeanization of migration policy and politics in Germany. In: Faist, T. \& Ette, A. (Eds.). The Europeanization of national policies and politics of immigration. Between autonomy and the European Union. Basingstoke [England]; New York: Palgrave Macmillan, pp. 73-92.

Radaelli, C. (2003). The Europeanization of Public Policy. In: Featherstone, K. \& Radaelli, C. (Eds.). The Politics of Europeanization. Oxford: Oxford University Press, pp. 27-56.

Risse, T., Caporaso, J. \& Green Cowles, M. (2001). Europeanization and Domestic Change. Introduction. In: Green Cowles, M., Caporaso, J. A. \& Risse-Kappen, T. (Eds.). Transforming Europe: Europeanization and Domestic Change. Ithaca, NY: Cornell University Press, pp. 1-20

Sachverständigenrat deutscher Stiftungen für Integration und Migration (SVR). (2014). Deutschlands Wandel zum modernen Einwanderungsland. Jahresgutachten 2014 mit Migrationsbarometer [Germany's Change Towards a Modern Immigration Country. Annual Report 2014]. Retrieved from http://www.svr-migration.de/content/wp-content/uploads/2014/o4/ SVR_JG_2014_WEB.pdf

Sachverständigenrat deutscher Stiftungen für Integration und Migration (SVR). (2011). Migrationsland 2011. Jahresgutachten 2011 mit Migrationsbarometer [Migration Country 2011. Annual Report 2011]. Retrieved from http://www.svr-migration.de/content/wp-content/uploads/2011/04/jg_2011.pdf

Scharnitzky, Ralf (2011, July 23). Arbeitskräfte dringend gesucht [Workers Urgently Needed]. Süddeutsche Zeitung, p. R20.

Von Weizsäcker, J. (2006). Welcome to Europe: A European Blue Card Proposal. Retrieved from http://www.bruegel.org/publications/publication-detail/publication/48-welcome-to-europe/

Windhoff-Héritier, A., Kerwer, D., Knill, C., Lehmkuhl, D., Teutsch, M. \& Douillet, A.-C. (2001). Differential Europe. The European union impact on national policymaking. Lanham, Md: Rowman \& Littlefield Publishers.

Wirtschaftsministerkonferenz. (2012, July 18). Beschluss-Sammlung der Wirtschaftsministerkonferenz am 04./05.06.2012 auf Schloss Krickenbeck [Collection of resolutions of the conference of Ministers of Economy], Berlin. 
COMPARATIVE MIGRATION STUDIES

\section{About the Author}

Dr. Barbara Laubenthal, lecturer at the department of politics and public administration, University of Konstanz, Germany.

Email: Barbara.Laubenthal@uni-konstanz.de 